BULLETIN Bulletin hispanique

HISPANIQUE Université Michel de Montaigne Bordeaux

116-1 | 2014

Varia

\title{
Correspondencias, confidencias y contrapuntos
}

Andrés Sánchez Robayna y Antoni Tàpies

\section{Candelas Gala}

\section{CpenEdition}

\section{Journals}

Edición electrónica

URL: http://journals.openedition.org/bulletinhispanique/3281

DOI: 10.4000/bulletinhispanique.3281

ISSN: 1775-3821

Editor

Presses universitaires de Bordeaux

Edición impresa

Fecha de publicación: 1 junio 2014

Paginación: 415-438

ISBN: 978-2-86781-931-5

ISSN: 0007-4640

Referencia electrónica

Candelas Gala, "Correspondencias, confidencias y contrapuntos », Bulletin hispanique [En línea]

116-1 | 2014, Publicado el 01 junio 2017, consultado el 24 mayo 2020. URL : http://

journals.openedition.org/bulletinhispanique/3281; DOI : https://doi.org/10.4000/bulletinhispanique. 3281 


\title{
Correspondencias, confidencias y contrapuntos: Andrés Sánchez Robayna y Antoni Tàpies
}

\author{
Candelas Gala \\ Wake Forest University - USA
}

Le dialogue inter-sémiotique entre les poèmes de Sánchez Robayna et les dessins de Tàpies dans Sur une confidence de la mer grecque (2005) souscrit à l'idée de la «modernité inachevée" de Habermas. Entendant l'art comme un processus de raisonnement critique sur la réalité, leurs ouvres se fondent sur la corrélation entre l'épiphanie qui surgit de l'attention portée à des objets à première vue insignifiants et l'élégie inscrite dans leur nature évanescente.

Mots-clés : contrepoint, correspondance, épiphanie, élégie, matière, absence, présence.

El diálogo inter-semiótico entre los poemas de Sánchez Robayna y dibujos de Tàpies en Sobre una confidencia del mar griego (2005) se suscribe a la noción de "modernidad inconclusa» de Habermas. Su entendimiento del arte como un razonamiento crítico sobre la realidad se sustenta en la correlación entre la epifanía que emerge de la mirada atenta sobre objetos aparentemente insignificantes y la elegía ya inserta en su naturaleza evanescente.

Palabras claves : contrapunto, correspondencia, epifanía, elegía, materia, ausencia, presencia.

The inter-semiotic dialogue between Sánchez Robayna's poems and Tàpies' drawings in "On a Confidence by the Greek Sea" (2005) subscribes to Habermas' notion of "unfinished modernity". Their view of art as a process of critical reasoning on reality is based on the correlation between the epiphany that emerges from the focused attention on seemingly insignificant objects, and the elegy already inserted in their evanescent nature.

Keywords: counterpoint, correspondence, epiphany, elegy, matter, absence, presence.

$\mathrm{D}$ ecir de una palabra poética que es a la vez epifanía y elegía parece contradictorio a primera vista y, sin embargo, se aplica con justeza a la obra de Andrés Sánchez Robayna, una obra que se sostiene, como su mismo autor ha 
indicado, en el contrapunto entre esos dos términos ${ }^{1}$. Las epifanías que se dan en esta obra poética proceden de una observación atenta y reflexiva de la realidad que, como en una composición musical polifónica, incluyen el contrapunto elegíaco de su disolución.

Lo mismo se puede aplicar a la obra del pintor Antoni Tàpies para quien el arte es «un amar las cosas en su mortalidad» (La práctica, p. 185), un contrapunto entre trazo y espacio en blanco, signo e informalismo ${ }^{2}$. Sus enigmáticos lienzos parecen contener signos de alguna inminente revelación que, fijando nuestra mirada, invitan a penetrar más allá de lo que se ve en la superficie. Exigen, además, deshacerse del bagaje cultural que determina lo que vemos y cómo lo debemos de ver para ver de otra manera ${ }^{3}$. Más que una técnica, el contrapunto, en ambos artistas, es un entendimiento y actitud ante la vida y el arte.

El objetivo de este ensayo es analizar los contrapuntos y correspondencias que se establecen en la combinación de poemas de Sánchez Robayna y dibujos de Tàpies, tal y como se encuentra en el libro Sobre una confidencia del mar griego. Precedido de Correspondencias (2005). Atentos a las confidencias procedentes de su entorno, y cada uno en su propio medio, estos dos artistas exploran la base matérica de la realidad. En esta comunicación activa con las cosas resuena el proyecto de Jürgen Habermas de continuar el proceso de razonamiento que la modernidad aún tiene pendiente. Como el filósofo alemán, ambos artistas reconocen que la obra de arte puede ser una fuente de conocimiento y, al aplicarse a su búsqueda por rutas mentales, encuentran el contrapunto de dicho conocimiento subyacente en la realidad matérica.

Sobre una confidencia del mar griego incluye un total de treinta y dos poemas -doce en Correspondencias y veinte en Sobre una confidencia- junto con ocho dibujos de Tàpies. Se trata, entonces, de un libro con dos partes que, a su vez, pertenece a una colección más extensa titulada La sombra y la apariencia de 2010. Aunque en número los dibujos corresponden a uno por cada cuatro poemas, su función no es de servir como ilustraciones. Según comentario del poeta, Tàpies recibió el libro de poemas y elaboró los dibujos por asociación analógica con lo que los textos le sugerían ${ }^{4}$. Para Sánchez Robayna, los dibujos de su amigo

1. Sánchez Robayna reconoce que sus poemas convocan presencia y crean un lugar de epifanía. Ańade que todo poema es una elegía pues se expresa «en la más cerrada conciencia de la muerte, y precisamente por ella». Escribir poesía es «cantar» «sobre el incesante trabajo de la finitud» («Eṕlogo», pp. 432, 433).

2. El Arte Informal apareció en París hacia 1945 y parte de los intereses surrealistas de antes de la guerra, como el automatismo psíquico y el uso de materiales poco comunes de forma improvisada. Los surrealistas consagraron la idea de «informe» que hallaron personificada en Rimbaud, el poeta que siguió la consigna de Baudelaire de sumergirse en el abismo de lo «desconocido» para hallar lo nuevo. El informalismo busca hacer de la materia objeto de análisis (Ashton, p. 30).

3. Tàpies se pregunta: «¿Cómo hacer para mirar limpiamente, sin querer encontrar en las cosas lo que nos han dicho que debe haber, sino simplemente lo que hay?» Y a los comentarios sobre la dificultad de sus cuadros, el pintor responde que «todo el espectáculo de hecho no es nada, a menos que queramos o sepamos ver más allá de lo que hay» (La práctica, pp. 87, 188).

4. Comentarios de Andrés Sánchez Robayna en la reunión de la South East Modern Language 
Tàpies son «huellas y signos, a un tiempo dramáticos y contemplativos, [que] tan bien dialogan con la dimensión meditativa o reflexiva de estos poemas» («Dos prefacios», p. 27) 5 . Este diálogo entre ambas muestras artísticas podría llamarse una «inter-referencia» (Kibédi Varga, p. 39), pues constituye un entramado de relaciones entre ambas manifestaciones artísticas, así como entre los poemas y dibujos entre sí, y entre los poemas con otros dibujos y declaraciones del pintor ${ }^{6}$.

El titulo Correspondencias da una pista sobre este tipo de diálogo. La referencia más obvia es al famoso soneto de Baudelaire, "Correspondances», donde el poeta, como «traductor» $\mathrm{y}$ «descifrador», debe interpretar los mensajes que, en una mezcla de colores, perfumes y sonidos, emanan del templo vivo que es la Naturaleza. El poeta no puede recurrir a la causalidad para dilucidarlos, ya que todo se funde en una unidad profunda y tenebrosa. Su estado de percepción es de gran intensidad y agudeza y conlleva un sentido de expansión del espacio y el tiempo donde las cosas adquieren resonancias y la realidad se revela como un entramado de relaciones mutuas ${ }^{7}$. Otra posible resonancia del título es a la correspondencia matemática, es decir, la ley que asocia a cada elemento de un conjunto $\mathrm{A}$ a uno o más elementos de otro conjunto B. La correspondencia o función matemática concuerda con las correspondencias baudelerianas en descartar la causalidad, como ya estableció el físico austríaco Ernst Mach (1838-1916), y con el interés que ambos, poeta y pintor, han manifestado por las ciencias ${ }^{8}$.

Association, Atlanta, 4-6 de Noviembre, 2011. En una entrevista de 2006 explicó que «la imprenta realizó una maqueta [...] con una determinada serie de hojas en blanco sobre las que trabajaría el pintor. Esa fue la base sobre la que Tàpies hizo los dibujos. Intercaló las piezas donde él quiso, creando una serie de ritmos internos formados por los blancos, los textos y los dibujos [...] no se trata de un libro «ilustrado», sino de una obra conjunta» (Rodríguez-Refojo, p. 44).

5. Según Sánchez Robayna, los dibujos de Tàpies crean un espacio de diálogo con los poemas, siguiendo la tradición del libro-objeto (Rodríguez-Refojo, p. 42).

6. Como señala Monegal (p. 39), el método comparativo es insuficiente en casos como el de este libro ya que en vez de cosas distintas que comparar «Lo que tenemos son formas de relación, o ejes de tensión, entre registros que se dan dentro de un único discurso contenido en un objeto de múltiples dimensiones».

7. El soneto de Baudelaire dice: «La Nature est un temple où de vivants piliers / Laissent parfois sortir de confuses paroles; / L'homme y passe à travers des forêts de symboles / Qui l'observent avec des regards familiers. / Comme de longs échos qui de loin se confondent / Dans une ténébreuse et profonde unité, / Vaste comme la nuit et comme la clarté, / Les parfums, les couleurs et le sons se répondent. I Il est des parfums frais comme des chairs d'enfants, / Doux comme les hautbois, verts comme les prairies, I -Et d'autres, corroumpus, riches et trimphants, / Ayant l'expansion des choses infinies, / Comme l'ambre, le musc, le benjoin et l'encens / Qui chantent les transports de l'esprit et des sens» (pp. 22-24). Sobre el surnaturalism de Baudelaire, véase Scott, pp. 210-211.

8. Tanto Sánchez Robayna como Tàpies han confesado su admiración por las matemáticas así como por los avances de la física moderna con la que comparten su interés en la materia, foco de la obra de ambos. El encuentro de Tàpies en París con el crítico de arte Michel Tapié fue fundamental por la afinidad de los dos por un arte enfocado en la materia primordial. En 1953 Tapié declaró la necesidad de tener un arte digno «of the uncertainty principle, the logic of the contradictory, the unlimited rhythms based on the most complicated concepts of number, of forms reconstituted according to the continuity of the topologies of wholes, of thoughts enriched by the achievements of modern psychology in deep regions of the unconscious» (Ashton, p. 32). Tàpies halla inspiración también en una serie de fuentes científicas heterodoxas, como Stéphane Lupasco, la 
Los doce poemas en Correspondencias resaltan como evidencia o epifanía objetos, personas o eventos ya marcados por la ausencia?. Un pobre y escuálido almendro floreciendo junto a un muro; la madera de una silla rota; el cuerpo inerte de una joven militante; las víctimas del holocausto y de los ataques en Atocha; los muertos en cementerios; la fragilidad del esplendor de las flores; o el espacio aparentemente vacío, suponen focos donde la materia se vuelve radiante en su misma ausencia gracias a la atenta mirada del poeta. Uso el término «radiante» en el sentido de William Crookes (1832-1919) -el físico y químico inglés que creyó haber descubierto un cuarto estado de la materia, o «materia radiante», al ver el efecto de fosforescencia y calor que producen los rayos cátodicos sobre los objetos. En ese estado de la materia es donde según Crookes se encuentra la linde entre lo conocido y lo desconocido ${ }^{10}$. En esta línea, Sánchez Robayna percibe en objetos y eventos aparentemente inertes, o en proceso de desaparición, la convergencia de rayos energéticos, o lo que en física implica la concentración de una cantidad del campo en torno a un punto ${ }^{11}$.

A primera vista, sin embargo, no hay nada de convergencia energética o de «radiante» en el débil almendro que en el primer poema persiste en florecer junto a un muro:

teosofía y el misticismo. Su interés por el poeta catalán Joan Brossa, a quien Sánchez Robayna ha traducido al español, se debe a sus temas hipnagógicos. Su apego al proyecto surrealista se debe también a compartir con el surrealismo el mismo interés por el ocultismo como «a legitimate and intellectually respectable area of inquiry». Del místico Ramon Llull, conocido como «El Gran Fantástico», Tàpies toma sus conocimientos del sufismo, de los alfabetos y diagramas extrańos de anillos concéntricos y números y los signos ocultos (Ashton, pp. 27, 28). Para Sánchez Robayna, por su parte, la palabra proporciona un «conocimiento de lo impensable» que se corresponde con lo imponderable en física. Lo que el poeta llama carnalidad de la palabra nos permite «recordar en todo momento la propia materia del mundo», pues el impulso poético «no es otro que el hechizo de la fisicalidad del mundo». En los juegos fonéticos encuentra el poeta «el misterio esencial de la materia» («Epílogo», pp. 430-431).

9. Según Cirlot, el interés en Tàpies por las cosas pequeñas e insignificantes muestra la creencia de que es posible llegar por ellas a la revelación y el conocimiento. Además, es un medio de advertir la «expresión autónoma involuntaria» de ciertos elementos y complejos de materias, colores y líneas (Tàpies, pp. 66, 68). Para Sánchez Robayna, el muro, la silla, y otros objetos en las obras de Tàpies, «ingresan en nuestro mundo perceptivo no ya solo como objetos sino como realidades poseedoras de una materialidad descubierta, una corporalidad manifestada [...] esta pintura hace visibles los objetos y los signos, hace de ellos presencia» («Sobre Tàpies», p. 67).

10. Crookes estudió las propiedades de los rayos catódicos y el efecto de fosforescencia y de fuerte calor que producen sobre los objetos. Sería J. J. Thomson quien descubriera la naturaleza subatómica de esos rayos y sus corrientes de electrones negativos. Aunque la teoría de Crookes resultara errónea, sus experimentos fueron la base de descubrimientos radicales en los campos de la química y la física.

11. Jordi Doce dice que para Sánchez Robayna el poema es «la representación de una representación, donde los elementos del mundo físico son leídos como signos y los signos verbales se integran en el tejido matérico del mundo" (p. 118). Borja-Villel considera que a partir de los 50 se busca, en términos de Barthes, aprehender un grado cero del arte, «una nueva objetualidad, abandonando la realidad estática y exterior propia de la cultura y arte occidentales para acercarse a otra realidad en la que forma y materia se confundiesen» (p. 15). 
Verás, incomprensible,

Blanco, casi vencido,

Un almendro, de noche,

Florecer junto a un muro. (9)

No sólo su florecer en condiciones tan adversas resulta «incomprensible», sino que sus ramas, a pesar de estar disgregadas, son acogidas en el abrazo del Uno: "Verás ramas y tallos /en los brazos del Uno». La insistencia en el sonido cerrado de la-u- en palabras como «muro», «aún», «dura», «último», «muestra», «oscuro», «desnudos», sugiere la persistencia de ese escuálido almendro, culminando en el «Uno» donde su apariencia fragmentada se congrega. La posición estratégica de «muro» $\mathrm{y}$ "Uno» al final de la primera y tercera estrofas, realza la «carnalidad» de las palabras, por un lado, y lo que desde este poema inaugural ya contiene el núcleo de la visión de ambos artistas en sus respectivos medios: la materia en su presencia como unidad de la realidad ${ }^{12}$. La unidad de la materia engloba lo vegetal y lo mineral y comporta en sí el cambio temporal: el almendro está sujeto al tiempo cíclico y el muro a la erosión.

El dibujo que acompaña a este poema en el lado izquierdo de la página parece que emerge de por debajo del libro y de su sutura central. Como señala Cirlot (Tàpies, p. 17), es frecuente que las obras del pintor desborden los límites del cuadro y produzcan una impresión de profundidad, sugiriendo la tercera dimensión. En este caso, el dibujo emerge de las «entrańas» del libro, parte consustancial de su identidad. Las huellas dactilares podrían, entonces, pertenecer a una mano que soporta el libro y que sería la mano hacedora, tanto la del pintor como la del poeta, llevando el peso del libro/objeto artístico que, como lectores, nosotros también sostenemos en la mano. Pero esa mano es apenas presencia, siendo más la huella o ausencia de lo que fue. ¿Es la huella de esa mano, entonces, también la nuestra que, de esta manera, nos reconoce como participantes activos en la recreación por la lectura de estos poemas y dibujos a la vez que da constancia de nuestra progresiva disolución? Si así fuera, el dibujo, como el poema, convoca a la vez que dispersa.

Las huellas dactilares recuerdan las fotografías que Wilhelm Röntgen (18451923), el descubridor de los rayos X, hizo de la mano de su mujer, Anna Bertha (1833-1919). Los rayos X permitieron acceder a áreas que hasta entonces se habían considerado impenetrables, llevando hacia el conocimiento que Sánchez Robayna llama «de lo impensable» ${ }^{13}$. La materia dejó de ser una masa sólida e

12. Según Sánchez Robayna, el valor de iluminación de la poesía se produce en la palabra "como si la carnalidad de la palabra fuera del todo imprescindible para acceder a un conocimiento otro, a lo que he llamado el conocimiento de lo impensable» («Epílogo», p. 430).

13. Derrida habla de la huella o ausencia de la presencia que antes allí estuvo, mostrando que la realidad consiste en esa conjunción de presencia y ausencia o, en otros términos, de epifanía y elegía. La huella es, entonces, ese intervalo que tiene lugar entre los signos en la página y esos otros signos que han sido desplazados o diferidos de los cuales los que vemos en la página son tan sólo su huella o «trace». Derrida describe este intervalo como que el tiempo se espacializa y el espacio se temporaliza. La presencia lo es en base de la ausencia, del silencio. Se trata de una ilusión de presencia, produciéndose un tipo de iconoclasmo ya que «the spirit of signification is 
inerte para volverse visible y revelar su naturaleza cambiante ${ }^{14}$. La exaltación de la materia en este pintor es tal que las rugosidades, arañazos, grietas, hullas, marcas etc, parecen como si surgieran desde el fondo del lienzo o de su través (Cirlot, Tàpies, p. 145) ${ }^{15}$. Tàpies, por su parte, confiesa haberse ensañado con la tela del lienzo hasta llegar a un punto epifánico en que la materia se le reveló en «Sugestión de raras combinaciones y estructuras moleculares, de fenómenos atómicos, del mundo de las galaxias, de imágenes del microscopio». Estas revelaciones, según el pintor, acabaron en hacer de sus lienzos muros, como si en ellos se coagulara la materia (pp. 139, 140). Teniendo en cuenta que el significado del apellido Tàpies es muro o tapia, se diría que el pintor llega a transustanciarse con el material de su obra ${ }^{16}$.

Las huellas que parecen avanzar en el dibujo, como si se ofrecieran o quisieran obtener algo, topan con el trazo grueso, de igual modo que en el poema el muro es el límite para el almendro. Dicho trazo también se parece a las llaves que se usan en el discurso para contener algún comentario aclaratorio; se continúa en otros trazos como garabatos que tachan algunas de las huellas y que terminan en rasgos semejantes a los que se hacen en las firmas. Choca lo ausente de esa presencia de la mano con el grosor de la curva / paréntesis; lo violento de su trazo parece querer atrapar la fantasmagoría de la mano y dedos dentro de confines gráficos. Al mirar el último dibujo de la serie, con la curiosidad de confirmar si allí aparece el lado derecho del paréntesis, lo que hallamos es el mismo lado izquierdo de la curva, aunque más parecido ahora a un corchete, reducido en tamańo y casi aplastado por una forma geométrica. El lado derecho de esa curva/paréntesis/ corchete aparece en el dibujo a la izquierda de «Madrid, para una elegía», noveno poema de Correspondencias (pp. 24-25), circunscribiendo la palma de la mano. En todos los casos, el pintor contrasta trazos gruesos con otros mucho más débiles y manos como signos humanos con otros pertenecientes a la escritura, sugiriendo el dualismo vida/escritura, movilidad/fijeza. La orientación horizontal de estos dibujos elimina todo tipo de imposición jerárquica del nombre como autor/artista; más bien se deja constancia de una presencia física en trance de

served by the destruction of its "carnal monuments"» (Gilman, p. 19). Ambos Tàpies y Sánchez Robayna se interesan por los estadios evanescentes de los objetos, es decir, por la diferencia como lapso entre lo que aparece en la página y lo que estuvo allí antes, diferencia que implica lo temporal pues se enfoca en la metamorfosis de todo lo existente.

14. Para José Ángel Valente, Tàpies usa «la memoria de las formas que la materia tuvo -huellas de unos pies, de unos dedos ensangrentados». Añade que no hay distinción en la obra de Tàpies entre materia y espíritu, e identifica la cruz, tan frecuente en el pintor, como "símbolo unificador de la materia viva del mundo", integración de contrarios o, en otra palabras, del contrapunto que aquí nos ocupa (pp. 43, 44-45). Según Mayhew en el arte de Tàpies tanto el significante como el significado son materia en cierto sentido y por tanto igualmente espirituales (p. 94).

15. Cirlot comenta sobre el poder emocional que la materia tiene en Tàpies junto con la expresividad de sus rasgos y surcos, concluyendo: «La materia manda a la forma» (Significación, p. 23).

16. Según Cirlot, el muro es un medio de proteger la intimidad además de presentarse como un obstáculo para penetrar en el enigma del cosmos (Significación, p. 95). 
desaparecer, y en el primer dibujo, de la agrupación de cada uno de los dedos bajo el tutelaje del Uno.

Este dibujo muestra la complejidad del acto de la creación, acto que implica la presencia física del artista que, en el mismo gesto, anula dicha presencia: la epifanía de su marca conlleva su propia elegía o ausencia y las formaciones tienden a la disgregación. En este sentido, el almendro y el muro del poema adquieren un valor simbólico, signos icónicos del arte como correspondencia y contrapunto entre lo vegetal y lo mineral, el tiempo cíclico y el tiempo linear, la presencia y la ausencia, la forma y su disolución.

Aunque los dos artistas nos instan a que miremos con atención, estas dos primeras muestras ejemplifican la desnudez de recursos que caracteriza esta colección. Según Rudolf Arnheim (p. 7), el movimiento del arte hacia la abstracción en el XX ayudó a transformar el espacio en un campo dinámico de interacciones pero con escasas claves interpretativas. Por eso el espectador adquiere un gran protagonismo en el intento de esclarecer dicho espacio, a diferencia de la obra tradicional donde se contaba, principalmente, con un autor omnisciente. En el arte moderno el observador es parte de lo observado; su identidad viene dada por su relación con el entorno, mientras que la obra, a su vez, requiere de su intervención. Debido a la relatividad y movilidad de las interpretaciones, el espacio deja de ser vacío y estático para convertirse en un campo de fuerzas en intercambios constantes: "Space is filled with dramatic happenings» (Arnheim p. 8). Los dibujos de Tàpies muestran tensiones espaciales y procesos de formación y desintegración. Las correspondencias describen, entonces, la fusión del observador en lo observado y, como resultado, una visión no atomista del mundo que estos dos artistas comparten, y un conocimiento que es provisional pero creativo al emerger de una perspectiva siempre cambiante. Decir que todo se encuentra en proceso de transición es decir que todo se encuentra en constante metamorfosis ${ }^{17}$.

Es evidente que la lectura de este primer dibujo, como de los siguientes, procede en gran parte de mi intuición, aunque se sepa que ni la mirada ni la intuición sean ni ingenuas ni puras. El mismo Tàpies es muy consciente de que su obra cuenta con el espectador para ser interpretada, por eso escribió su tratado La práctica del arte, con el fin de hacernos "practicar» nuestra sensibilidad. El pintor sabe que «la realidad nunca ha estado en la pintura, sino que únicamente se halla en la mente del espectador» (p. 35). Por eso, cree que hay que confiar en el instinto pues sabe que sus dibujos se interpretarán según ese instinto, unido al bagaje cultural de cada uno (p. 43). La falta de tema en sus dibujos, y en su obra, en general, es tal que nos obliga a ejercitar la imaginación y a prestar atención al acto creador mismo, a la obra tal y como se presenta ante nosotros (Cirlot, Tàpies, pp. 147, 150). Hay que tener en cuenta, también, que este acercamiento no agota

17. Según Sánchez Robayna, en los dibujos de Tàpies se trata de «signos que sólo se significan a sí mismos como expresiones de una presencia, de una materialidad o una realidad en la que está cifrada lo humano» («Sobre Tàpies», p. 59). 
las interpretaciones pues se trata sólo de una lectura entre otras posibles ${ }^{18}$. Los dibujos de Tàpies ofrecen grandes dificultades pues lo que allí vemos no parece codificarse dentro de ningún sistema de significación reconocido (Greimas, p. 631). Ante ellos nos encontramos con una casi total ausencia de transparencia referencial. El medio de subsanar la dificultad, al menos en parte, se encuentra en la iteración de signos que en los dibujos llega a formar un sistema cuyo significado hay que determinar. Otra dificultad es que estos dibujos carecen de marco. Como señala Bethany Johns (p. 299), el marco establece la tensión entre el espacio y el límite, lo que supone, al mismo tiempo, cierre e infinitud, límite y variación. Como índice, el marco controla los fragmentos, pero también los crea. Sin marco definido, la página emerge como espacio con sugerencias de infinitud. De esto se desprende que los dibujos no se nos dan como hechos, como construcciones con un sentido marcado de antemano, sino que está en nosotros, como espectadores, el volverlos inteligibles mediante una lectura (Greimas, p. 636). Aplicando la noción de "estructura planar" " de Greimas a estos dibujos (p. 629), se puede hablar de ellos como un todo significativo en el que hay que considerar todo tipo de inscripción o marcas, por ínfimas que sean ${ }^{19}$.

Aunque no halla dibujo que acompañe al poema "Madera de una silla rota» (p. 11), su texto se enlaza directamente con el texto de Tàpies incluido en $L a$ práctica del arte sobre una vieja silla, así como con varias de sus obras sobre sillas. Ambos artistas evocan todo lo que implicó el construir y disfrutar la silla de «fatiga y reposo,/[...] convivir pacífico» (p. 11); Tápies se refiere, además, a su origen en el bosque y a la ilusión de quien la compró (La práctica, p. 87). Tanto el texto del pintor como el poema hacen hincapié en mirar con atención: «Mírala: / ama lo destruido,» instan los versos finales del poema, y Tàpies dice: "Mirad el más sencillo de los objetos. Tomemos, por ejemplo, una vieja silla» ${ }^{20}$. Sólo una

18. Se trata de adquirir una «visual literacy» [alfabetismo visual] ya que hay que «leer» configuraciones tipográficas, pictóricas y diagramáticas y lograr reconocer los aspectos que sirven para comunicar información o participar en la constitución y percepción del sentido (Johns, p. 291). Aldrich habla de metáforas visuales como experiencia estética que hay que analizar para acabar así con el viejo prejuicio de que hablar de imágenes es algo muy subjetivo. Según este crítico, la experiencia metafórica nos fuerza a ver algo como algo más o algo diferente y a analizar lo que eso implica (pp. 73, 75).

19. Greimas sugiere la aplicación a estas estructuras planas de ciertas "grids», es decir, redes o modelos, cuyo sentido va determinado por el contexto espacio-temporal, y que convierten los trazos plásticos en signos/objeto creando así un tipo de texto plástico. Dichos modelos deberán tener en cuenta el lugar o posición de los trazos en la página, su orientación, la distancia y/o proximidad entre ellos, y su distinto grado de grosor, entre otros aspectos; es decir, las «categorías topológicas» (periféricas/centrales; arriba/abajo; derecha/izquierda, curvilíneas) (pp. 633, 638).

20. Y continúa, «Parece que no es nada. Pero pensad en todo el universo que incluye: las manos y los sudores cortando la madera que un día fue árbol robusto, lleno de energía, en medio de un bosque frondoso en más altas montañas, el trabajo amoroso que la construyó, la ilusión que la compró, los cansancios que ha aliviado, los dolores y las alegrías que habrá aguantado, quien sabe si en grandes salones o en pobres comedores de barriada...Todo, todo participa de la vida y tiene su importancia. Hasta la silla más vieja lleva en su interior la fuerza inicial de aquellas savias que ascendían de la tierra, allí en los bosques, y que aún servirán para calentar el día en que, astillada ya, arda en algún lugar» (p. 87). 
mirada atenta a la materia, por derruida y fragmentaria que sea, puede conducir a la linde de un conocimiento nuevo, parte de una Unidad que hay que descifrar. En "Silla» de 1983 hecha de cerámica con una enorme cruz en aspa; o "Silla y ropa» (1970), y más particularmente «En forma de silla» (1966; Triadó Tur, pp. $75,61,47)$, se trata de activar una percepción nueva de la silla más allá de su función: la silla en cuanto materia. Así, en «En forma de silla», la diagonal que raja agresivamente el estilo burgués y convencional de la silla enfatiza la materia de que está hecha. Al continuarse en recta por la parte de atrás y con el marco hasta formar un triángulo, este juego de líneas logra destacar la geometría elemental de la silla que su forma burguesa ha querido elidir. Si, como señala Malpartida, el lenguaje en Sánchez Robayna no es algo establecido pues en sus signos se asiste a «una transfiguración verbal del mundo que perciben los sentidos» (p. 43), los trazos en las obras de Tàpies revelan la base matérica como lo sustancial. Por eso ambas obras son tanto metalingüísticas y metapictóricas como físicas. Lo que estos artistas se proponen es devolver al mundo "su mismidad» de modo que la palabra o trazo no estén en el lugar de otra cosa, sino en su lugar (Malpartida, pp. 44, 47).

Hay tres poemas que tratan de víctimas de distintos actos de violencia: Rachel Corrie (p. 13), la activista norteamericana de 23 años que el 16 de marzo de 2003 fue aplastada por un tanque israelí al colocarse delante de una casa palestina para evitar que fuera demolida; las víctimas del Holocausto judío («Homenaje», p. 15); y las del ataque a la estación de Atocha de Madrid el 11 de marzo de 2004 («Madrid, para una elegía», p. 25). En los tres casos los cuerpos muertos se exponen en una epifanía claramente elegíaca para ser transfigurados por el arte. El cabello rubio de Rachel Corrie «alumbra el aire» y su «mejilla nos honra», y «el surco / de la impiedad» donde fue abatido el cuerpo de la joven se suplanta por «Este otro surco», el del poema alzado en su memoria. Y si el lenguaje fracasa para expresar la magnitud de la tragedia, como anuncia el epígrafe de Dante al poema sobre los ataques en Madrid, "Ogne lingua per certo verría meno» [Toda lengua fracasará de seguro], la «claridad de la sangre» (p. 25) de las víctimas no deja duda de que esos muertos siguen siendo testimonios de la vida que, irónicamente, sólo el arte puede revelar. En «Homenaje» es la porosidad de la música del compositor H. M. Górecki que, junto con la voz de la soprano, elevan a las víctimas del nazismo hacia un nivel más allá de la muerte:

La voz asciende, nítida, de cuerpos arrasados,

Del humo y la ceniza, de pozos que aún se ahondan,

De muertos que ya nunca volverán a morir,

Oh música porosa.

En los tres casos se trata del arte iluminando la destrucción en eventos de la actualidad más apremiante y revelando, en lo que es su realidad más matérica, así como su transfiguración.

El dibujo ya mencionado a la izquierda de "Madrid, para una elegía» presenta una huella de la palma de la mano circundada por los trazos gruesos 
y arqueados que venimos identificando como posibles paréntesis o corchetes. Apenas se pueden ver las huellas de los dedos, y el foco se sitúa en esa palma donde sobresalen las líneas, como si se tratara de un manuscrito o un mapa que hay que interpretar. Según Sánchez Robayna: «El dibujo de Tàpies, sin duda, tiene para mí una clara relación con el símbolo de las "manos inocentes" (pintadas de blanco) con el que en muchas manifestaciones se protestó en España contra el terrorismo (especialmente cuando se produjo el asesinato de Miguel Ángel Blanco en 1997)» ${ }^{21}$. El dibujo puede leerse también en un sentido más figurativo, teniendo en cuenta que Tàpies habla de sus dibujos como talismanes y Sánchez Robayna del elemento órfico de sus poemas ${ }^{22}$. Además, y como las huellas dactilares del primer dibujo, la palma en éste evoca las fotografías de rayos $\mathrm{X}$, indicando una ruta para indagar en su posible sentido más allá de la visión superficial. Al hallarse circundada por esas llaves, el sentido de esa palma estaría en suspense, apuntando a las limitaciones del conocimiento ante los imprevistos del azar, y a la fragilidad de la presencia humana ya circunscrita por su fijeza en la escritura. "Madrid, para una elegía», a su vez, capta los imprevistos del azar en el rápido tránsito de un verso, donde los viajeros son «mejillas presurosas», al siguiente donde han sido reducidas por el ataque a un «amasijo de hierros en el alba». El choque de estas imágenes contrapuestas se continúa en la siguiente estrofa con la escena de los testigos de la tragedia: «Claridad de la sangre. En el crepúsculo / se juntaron los rostros silenciosos». El poeta aclara que la segunda estrofa se refiere «a la multitudinaria manifestación realizada en Madrid en señal de protesta y de duelo por los atentados. Los «paraguas» mencionados se deben a la intensa lluvia que cayó esa tarde-noche» (correo electrónico).

Este poema refleja el interés que Sánchez Robayna ha confesado por las asociaciones y contraposiciones que se dan en el interior del verso, entre sonidos fónicos así como entre los versos en sí, haciendo que los campos de percepción y de sentido se unan de manera imprevista y el lenguaje revele «no sólo lo no buscado, sino también, literalmente, lo no sabido, y que sólo después de la escritura se ofrecía en todo su poder de sugestión, en su misteriosa potencialidad cognoscitiva». La palabra resulta ser una iluminación «de tinta» oscura «como luz negra» con revelaciones inusitadas ("Poesía y poética», pp. 42, 37) ${ }^{23}$. Juan Goytisolo así lo entiende cuando dice que la poesía de Sánchez Robayna es

21. Comentario del poeta en el simposio de SAMLA ya mencionado y en correo electrónico del 18 de enero, 2012.

22. Sánchez Robayna confiesa identificarse plenamente con Mallarmé y su entendimiento de la palabra poética como " "una explicación órfica de la tierra" " capaz de "revelar"» el misterio del mundo. Del poeta francés toma "la concepción del lenguaje como un "diseño" [...] [un] "proyecto" [...], un trabajo de reticulación lingüística, una suerte de modelado verbal realizado por el sonido y el sentido» («Poesía y poética», p. 29).

23. Según Fernando Galván y Manuel Brito, la exploración del lenguaje, tan importante en Sánchez Robayna, cuenta mucho con la poética Zaum, un prefijo que significa «más allá», «detrás», y mente o nous; se puede traducir como «más allá de la razón» y describe los experimentos lingüísticos en simbolismo del sonido y creación del lenguaje de los futuristas rusos como Khlebnikov y Kruchenkykh. Se trata de un lenguaje poético experimental caracterizado por lo indeterminado en el sentido (p. 67). 
«la estrictez nodular del verbo, ceñido a lo elemental» (cit. Jordi Doce, p. 116). Sánchez Robayna, por su parte, habla de su poema como un espacio «en que tiene lugar el diálogo entre la imaginación fonológica y la indagación metafísica» y donde "el conocimiento está contenido en la imaginación» (Jongh Rossel, p. 157). Lo que cuenta son «las relaciones, las vibraciones, los intersticios de la visión, que la palabra inventa» («Dos prefacios», p. 27). En poema y dibujo se encuentra el contrapunto entre movilidad vital y fijeza mortuaria, presencia y ausencia.

En «Una sombra» (p. 17), la escena inicial de «Gaviotas en el claustro viejo: / luz, ala y piedra unidas", confronta la permanencia de la piedra de ese claustro con el movimiento cíclico y repetido del tiempo en las gaviotas y ambos, a su vez, con el "quién» es la sombra que las mira y que ya visitó antes el claustro. El tiempo ha transformado esa presencia en sombra imposible de reconocer, frente a la piedra en su permanencia y las aves en su retorno cíclico. En el dibujo correspondiente a este poema, la $\mathrm{T}$ identitaria es más una $\mathrm{X}$, sugiriendo el desconocimiento y la indagación a los que alude también el poema, y se sitúa hacia el lado izquierdo como si estuviera considerando para la escena diferentes posibilidades semánticas. Según Cirlot, la $\mathrm{X}$ puede ser una tachadura, el signo de la multiplicación y un centro dinámico en cuyo eje se cruzan las dos aspas sugiriendo nuevas posibilidades (Significación, pp. 107-108). Según eso, los dos borrones negros que parecen ojos enmarcados por líneas curvas a modo de cejas sugieren un mirar indagador ${ }^{24}$. Tienen encima un trazo que parece un montículo, o podría ser un seno, o, tal vez, una sugerencia de algún edificio (¿el claustro?) bajo el cual hay un garabato que podría leerse como un planeta con sus satélites o el zig-zag de algún vuelo. Hacia el lado derecho hay borrones ligeros que podrían ser huellas dactilares. Hay un contrapunto visual entre los trazos más ligeros de la parte superior y la persistencia de los borrones/ojos. Las huellas muy ligeras de la derecha son más bien "sombras» de huellas. La opacidad de los «ojos», por ser negros, se correspondería con la imposibilidad de «reconocer» en el poema debido al cambio producido con el paso del tiempo; el arqueado de cejas sugiere perplejidad ante esta metamorfosis y la persistencia del misterio. La preeminencia del mirar en este dibujo lleva en sí inscritas las limitaciones en su capacidad para revelar el misterio en el paso del tiempo.

En los poemas sobre cementerios (p. 19 y «Cementerio del Testaccio», p. 23), se reitera la disolución de la identidad en el transcurso temporal. Las piedras de las tumbas son ahora «Silencio / de cal» (p. 19) y "piedra de la ignorancia» (p. 23), pues los nombres de los muertos se han borrado con el tiempo. Los poemas dan testimonio de esos muertos, de sus tumbas no inscritas, como epifanías elegíacas de lo que fueron ${ }^{25}$. Como contrapunto a las flores secas sobre

24. Según Sánchez Robayna, la $\mathrm{X}$ es «destrucción y epifanía, axis mundi y centralidad, encrucijada y conjuro, confluencia y tachadura». Y citando a Wallace Stevens, la define como "The vital, arrogant, fatal, dominant $X$," es decir, una presencia que se hace visible incluso cuando se trata de tachar, destruir, anular otra imagen» («Sobre Tàpies», pp. 55, 61).

25. Hay contrapuntos también entre el mismo sol de junio en el cementerio por el que el Niño Dios anduvo en un principio, cuando las calles aún eran blancas y «piedra y cielo nacían / 
«la losa caliente» (p. 19), el siguiente poema se extasía ante la epifanía de las gerberas amarillas (p. 21), «soles multiplicados [...] puro poder de luz». Muerte y resurrección, elegía y epifanía, se dan en el simple gesto de pasar la página. Pero esta luminosa victoria sobre el tiempo queda disminuida cuando el amarillo y naranja de las flores se vuelven «-flores / de qué tumba ... lágrimas / del sol». Los encabalgamientos acentúan el contrapunto y correspondencia entre los elementos vitales y mortales, poniendo en evidencia la carnalidad de las palabras y la complementariedad de epifanía y elegía, de vida y muerte. Si al principio las gerberas en la ventana eran manos abiertas a gozar de su vitalidad, al final se trata de un frescor "confabulado» pues su apariencia de vitalidad lleva inscrita la muerte. Lo que de primeras parecía una invitación abierta a gozar de la vida en esas manos, se convierte en el «omnia mors / poscit» del final.

En otros poemas, sin embargo, la piedra es «sabia» porque sirve para dar forma al vacío. En «Tras las columnas, el vacío» (p. 27), las columnas son sinécdoque de algún templo o monumento y se sitúan en contrapunto con el espacio colmado por el vacío. El ojo humano, situado desde esas columnas, tiene una perspectiva del cielo como un ojo hueco y cóncavo. Gracias a las columnas se logra una geometrización de algo informe como es el espacio. En «Sobre un trono de piedra» Dedicado a Ludovisi. Palazzo Altemps (p. 29), la piedra se vivifica mediante la ecfrasis donde se acentúan los aspectos más sensuales de la escena de Venus con sus ninfas: los cuerpos desnudos, los brazos mojados, la luz carnal, la ansiedad de las manos, el deseo en los hombros. El final declara que «No hay destrucción» de la piedra, «la materia inmortal y materna» a la que volveremos. Frente a la «piedra de ignorancia» en el cementerio, esta piedra es el trono de la memoria logrado o conquistado por el arte.

En «La calle blanca» (p. 31), último poema de esta serie, el hablante llega «hasta los bordes, / hasta el lugar abierto, una calle vacía, / en los ojos del sueño inmemorable». La blancura de la calle y los altos muros son iconos del silencio a la vez que proclaman que «todo va a consumarse». El final de este recorrido es el mismo que el punto de partida, la hoja en blanco, indicando que aún todo queda abierto pues no hay soluciones definitivas y el camino está siempre por hacer. Lo que se revela o epifanía es lo que permanece ausente.

La "confidencia» en el título de la segunda sección del libro procede del mar griego cuyos espacios, como indica Sánchez Robayna, son «de encuentro y revelación» («Dos prefacios», p. 27) ${ }^{26}$. Más que recaer en los lugares comúnmente asociados con la civilización griega y su papel en la cultura occidental, estos poemas dialogan con el paisaje del archipiélago, revelando un interés insular que

dentro de la mañana», y el que ahora azota los setos y las piedras silenciosas. En esas referencias, al Niño Dios y al azote del sol, se sugieren el nacimiento de Jesús en Belén y su Pasión y muerte, corroborada ésta en la losa caliente, como sucesos simultáneos. El pretérito «anduvo», tan obviamente situado en el primer verso, y tan definitivo y terminado que no parece que se vuelva a andar por allí, connota el olvido y la muerte. El que ha triunfado aquí es el tiempo.

26. El poeta confiesa tener «una profunda devoción por la cultura cicládica, por sus misterios y por sus bellas figurillas de mármol» («Dos prefacios», p. 27). 
se conecta con el origen canario de Sánchez Robayna (n. 1952) ${ }^{27}$. Desde su libro Clima (1978) hasta La roca (1984), este poeta se ha confesado investigando «el sentido o el destino de lo insular [...] como forma poética, como un modo de conocimiento y como una raíz espiritual; un irrenunciable modo insular, en fin, de estar en el mundo» («Poesía y poética», p. 32) ${ }^{28}$. La insularidad, con su contrapunto entre la verticalidad aislada y esencial de cada isla y su relación horizontal con el conjunto de islas en el archipiélago, se corresponde con los modelos sintagmático y paradigmático del discurso de Jakobson pues, según ya apunta el mismo Sánchez Robayna, la reflexión sobre las islas implica la del lenguaje («Poesía y poética», pp. 32-33). Si el sintagma, como relación entre los distintos elementos de una cadena de signos tiene que ver con la horizontalidad de dicha cadena, el paradigma es un modelo o esquema formal vertical donde se da la relación entre un elemento y los que lo podrían sustituir en otro contexto en la misma cadena, excluyéndose mutuamente. El paradigma supone, por tanto, un estado de exclusión -es una cosa u otra- mientras que el sintagma incluye varias opciones contrapuestas a la vez. Tàpies también trabaja con la composición de sus dibujos creando constantes tensiones espaciales entre horizontalidad y verticalidad, entre la dirección hacia la izquierda o la derecha con espacios vacíos que sugieren la vacuidad del mundo (Cirlot, Significación, p. 41).

En Sobre una confidencia del mar griego lo fragmentario de cada isla se da junto con la unidad del conjunto del archipiélago. Se podría aplicar a esta colección lo que indica Jordi Doce, que Sánchez Robayna crea series de poemas que funcionan como si fueran archipiélagos pues apuntan «a un eje o sentido central

27. Nacido en Las Palmas (Canarias, 1952), Andrés Sánchez Robayna ocupa la cátedra de Literatura Española en la Universidad de La Laguna, en la isla de Tenerife. Viene publicando poemarios desde 1978, además de numerosos libros de crítica y ensayo y traducciones. Premio de la Crítica de 1985 por La Roca (1984), traductor de la poesía de Salvador Espriu, por lo que obtuvo el Premio Nacional de Traducción entre lenguas españolas junto con Ramón Pinyol en 1982, así como de Wallace Stephens, Wordsworth y otros, entre 1983 y 1993 Robayna ha sido director de la revista de literatura, arte y crítica, Syntaxis. También ha dirigido la sede canaria de la Universidad Internacional Menéndez Pelayo y actualmente está a cargo del taller de Traducción literaria de la Universidad de La Laguna. En un ciclo inicial de sus obras se cuentan: Clima (1978), Tinta (1981), La roca (1984), seguido de Palmas sobre la losa fría (1989), Fuego blanco (1992) y Sobre una piedra extrema (1995). Un ciclo nuevo parece iniciarse con El libro, tras la duna (2002). Entre su labor crítica destacan estudios sobre Alonso Quesada, Góngora, poetas canarios de los Siglos de Oro, Sor Juana Inés de la Cruz, y Cairasco de Figueroa, entre otros. Es autor de dos volúmenes de diarios publicados en 1996 y 2002. Se le suele relacionar con los escritores de los años 70, específicamente a partir de 1972, como parte de una oleada de renovación poética espańola caracterizada por la atención al lenguaje y al poema como espacio autosuficiente en el que aquél reflexiona acerca de sí mismo (R. Fernández Hernández, p. 104).

28. Según Laura López Fernández, la marginalidad semántica y geográfica hay que entenderla como «una propuesta estética» (p. 173) pues Sánchez Robayna esencializa el paisaje canario; las islas reflejan los límites del lenguaje y del ser: «el espacio insular y la palabra poética forman una conjunción esencial que forma su peculiar universo ético-estético» (pp. 171, 172). Para Nilo Palenzuela, los textos de Sánchez Robayna quieren ser "una auscultación de la condición insular como un modo de habitar una imagen del mundo». Y Rafael Fernández Hernández indica que a Sánchez Robayna «le interesa la explicación órfica del mundo a través de la revelación» (p. 105). Para ello se apoya en el mito de la insularidad como «un modo de habitar una imagen del mundo». 
que subsume y trasciende cada una de sus partes» (pp. 115-116) ${ }^{29}$. Mediante paronomasias, aliteraciones, anáforas etc., la palabra entabla relaciones polifónicas con otras palabras en transmutaciones que buscan un eje o sentido central en el «designio de religación» («Epílogo», p. 428), entendiendo la religación como un «re-ligare», es decir, un re-establecer los lazos perdidos del signo con la materia. Para Sánchez Robayna la palabra es segunda a la materia y la luz, y supone un juego secundario de transmutación y transubstanciación que en sí marca su cariz altamente temporal («Epílogo», p. 427).

Con la escena del alba del primer poema (p. 35) se destaca ya la intención de dar consistencia material a un fenómeno que tan etéreamente se ha tratado en la tradición:

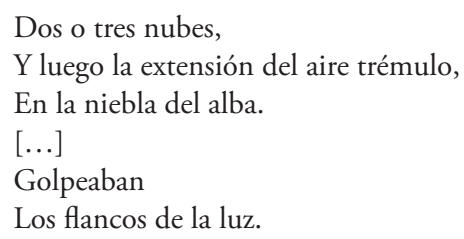

«Esos signos herían», dice el poeta al percibir el aire "trémulo» y el mar abriendo sus párpados y golpeando «los flancos» de una luz convertida en un animal de montura. Ya no se trata de mirar el paisaje como objeto de belleza, sino de descifrar sus signos y sus efectos transformadores en el espectador.

El dibujo en el lado izquierdo del poema se ha reducido a una huella dactilar, posiblemente la del pulgar, en orientación vertical, y a un grueso trazo horizontal situado por encima. Ambos aparecen en la parte inferior de la página y un poco hacia el margen izquierdo, evitando el protagonismo centralista. El minimalismo de una sola huella sugiere una limitada presencia humana y hacedora; es el espacio, como en el poema, lo que domina en toda su vacuidad. Verticalidad y horizontalidad se aúnan en la huella y el trazo, como contrapuestos y complementarios, formando la $\mathrm{T}$ del nombre del artista. Sugieren un entendimiento de la identidad y del lenguaje donde se funden lo esencial y lo relacional.

La misma configuración se da en el archipiélago griego donde cada isla está enhebrada al conjunto por la luz. "Esta dispersa teoría de islas» (p. 37) es como la describe el «aprendiz de la luz» (p. 43) que es el hablante y cuya meta es descifrarla en su sentido. Una teoría consiste de hipótesis y reglas y su objetivo es formular modelos científicos que las validen y expliquen. Los instrumentos de indagación en este libro son los sentidos, principalmente la vista pero también el oído («Escuchaste / [...] / un rumor, una sílaba casi, / entre las aguas», p. 39). El rumor del mar le llega al hablante desde la región de lo no dicho o indecible, y es él quien debe de conducirlo hasta lo decible. La Y inicial del cuarto poema: «Y poco a poco el sol, en su dominio, / se adueñó de las aguas, y dio sombra / a

29. Sánchez Robayna concibe esta segunda parte «como un solo poema, un texto unitario formado por cierto número de fragmentos» (Rodríguez-Refojo, p. 40). 
la espuma, creó la oquedad de las olas» (p. 41), indica su enlace con lo anterior, el suceder ininterrumpido y el avance paulatino en el descifrar la teoría que, a su vez, sugiere el enlace de las islas dentro del conjunto del archipiélago. Ante los ojos se despliega la danza deslumbrante del mar con el sol brillando en sus aguas en una escena de dimensiones míticas que le llevan al hablante a evocar los dioses de la mitología; la epifanía de fenómenos naturales que se despliega ante sus ojos posee un código que hay que descifrar ${ }^{30}$. Mediante el polisíndeton con -y- (poema 4), que sugiere entusiasmo, acumulación y sucesión, el lenguaje corrobora la energía cósmica de la escena desplegada en el constante movimiento de periodicidad del mar.

La materialidad del paisaje se ejemplifica en la casa que el hablante encuentra en su recorrido (poema 5). Su cal blanca relumbra como luz materializada y signo de la duración: «En la isla, perpetuo/aprendiz de la luz, viste la casa/construida por soles». El acceso a ese recinto se ve impedido por una verja, equivalente a los trazos que parecen establecer límites en los dibujos de Tàpies, y que da constancia de ser obra de la mano humana. El lenguaje articula la distancia que la verja establece entre hablante y casa mediante un espacio bien definido entre las dos estrofas -ese «entre» donde tienen lugar las relaciones e intercambios que constituyen la realidad, espacio intermedio entre epifanía y elegía. Por eso la aliteración en los términos contrapuestos de «morir» y «mirar»-«fluir, morir, mirar en sus umbrales/la belleza que llega en la brisa salina» (p. 43) -sugiere la metamorfosis e intercambios entre mortalidad y permanencia. El poema y sus recursos verbales aluden a la transustanciación de ser humano y materia, de lo temporal a lo perenne. En el poema 8, «En la capilla diminuta, exvotos» (p. 49), se trata de los exvotos u ofrendas dejadas como recordatorios en capillas e iglesias por los fieles que han recibido un don o curación, muestras del deseo de sobreponerse al olvido en el tiempo. Por eso el hablante le pregunta al «cáliz de preservaciones» de la memoria sobre qué signos del verano mejor representan «nuestro ser de esperanza», pregunta que queda sin respuesta.

El dibujo en la página 42, a la izquierda del poema cinco, «En la isla, perpetuo", es casi graffiti pues consiste de una serie de cruces, o de las letras T o $\mathrm{X}$ en fila vertical en el margen izquierdo. El resto del espacio queda en blanco, como si el trazo o huella humanos de las cruces estuviera contemplando esa inmensidad enigmática y aparentemente vacía. Apenas se pueden ver algunos restos de las huellas dactilares saliendo de la costura media del libro: ¡es que la mano del hacedor ya se ha borrado y de él sólo queda la inicial de su nombre y un espacio inmenso por descifrar? Si suponemos que la $\mathrm{T}$ o X reúnen los niveles sintagmático y paradigmático del lenguaje, su aparente confrontación con el espacio en blanco a su derecha connota el alcance de su indagación y la persistencia del desconocimiento.

30. En el poema 6, y volviendo a la mitología (p. 45), el hablante se pregunta: «¿Cada cosa tiene un dios, dijiste? / [...] / ¿Cuál es el dios, entonces, / [...] / del deseo del ser?» Los humanos comparten ese deseo con los guijarros por ser de la misma materia. Sólo sabiendo quién es ese dios podría el hablante entender las palabras que le dice el mar. Rodríguez-Refojo explica que el «todo está lleno de dioses» alude al filósofo griego Tales de Mileto (Tàpies / Sánchez Robayna, p. 15). 
En su continuada indagación sobre la teoría dispersa de las islas el hablante llega a constatar que «En la extinción de toda luz, un círculo / de la corriente de la luz se cumple» (p. 47). Partiendo de una escena de velas que se mueven entre las cúpulas, con la luz declinando en el atardecer, este poema reflexiona sobre la repetición cíclica: «Como anillo en el árbol, toda vida / añade con dolor un círculo a la luz». El «aprendiz de la luz» que es el hablante implícito de estos poemas constata que la luz se constituye en base de las vidas que se consumen y consuman en el tiempo. Así como es la luz la que «enhebra» y enlaza los distintos elementos de la realidad, es la luz también la que desenhebra y disuelve. El contrapunto al que le ha llevado su reflexión es que la luz, que ilumina y da vida, también consume y acaba cegando ${ }^{31}$.

El contrapunto entre luz y consumación, memoria y olvido, comienzo y fin, epifanía y elegía, se enfoca en la figura de una joven nórdica viajando con su mochila a la espalda del poema nueve, «La luz cegaba». En el entusiasmo de su cara al iniciar su aventura el hablante percibe ya la marca de su fin:

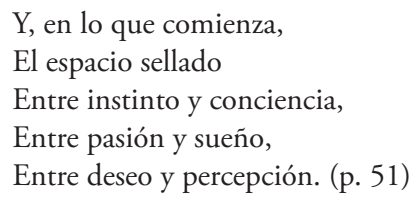

Las parejas de elementos en estos versos están contrapuestos por un «entre»o espacio intermedio que está sellado. El instinto, la pasión y el deseo de la joven se confrontan con la reflexión, la irrealidad y la relatividad de sus percepciones. El final del poema especifica sobre ese espacio: «Entre el mar y la casa, / el espacio de cosas que no reconocemos, / pues son ellas las que nos reconocen». Las cosas que ocupan ese espacio intermedio entre el mar abierto y la casa como hábitat humano nos reconocen por estar hechos de su misma materia. El reverso no se da, por el distanciamiento entre el raciocinio humano y la naturaleza. Las cosas poseen un conocimiento del que debemos aprender. De igual modo, los dibujos de Tàpies parten del ejemplo de la materia, creando la realidad en el proceso de pintar. Desde el ocaso al comienzo del poema, pasando por el retrato de la muchacha nórdica, el hablante ha meditado sobre el contrapunto entre posibilidades y límites, comienzos y finales. El ser humano ya no ocupa el centro del saber que ahora radica en las múltiples perspectivas de las cosas.

La indagación en los signos que se está llevando a cabo en este libro va revelando que lo esencial de nuestro ser es la materia, de ahí el deseo de transmutarse en ella, de «re-ligarse» con lo matérico que un excesivo intelectualismo ha ido borrando.

31. Según Laura López Fernández (p. 174), todo se funde con la luz que a la vez que ilumina, ciega, disuelve y muestra lo transitorio de la realidad. El fenómeno óptico de los «círculos de la luz» aparece cuando el sol ya ha salido, o bien, sólo se ven temprano por la mañana o al mediodía o por la tarde. Algunos son visibles en primavera u otońo e incluso bajo la luz de la luna. A veces aparecen en el mismo sitio o bien se dan por un tiempo y luego desaparecen (ver http://www. share-es.org/2000/sign0900.htm). 
Es interesante, entonces, que el dibujo junto al poema nueve en la página 50 vuelva a las huellas dactilares que habían ido desapareciendo en los anteriores. Son fantasmagóricas, como si se tratara de exhalaciones extendiéndose hacia el margen izquierdo donde hay unas letras que parecen del alfabeto griego. Estas huellas sugieren el deseo de unirse con los signos, de cubrir ese espacio «entre» que describe el poema y lograr descifrar el mensaje oculto en esas letras.

Como indica el poema diez, todo es un fragmento de una unidad a la que hay que descifrar. ¿Se encuentra dicha unidad en el «punto candente del instante que gira» (p. 55), el que el hablante observó en las aguas del mediodía frente a Naxos? A pesar de lo epifánico de la experiencia, «Las aguas te decían otra vez / su palabra ignorada». En el poema 14 (p. 61), «el punto destellante en las aguas» es la imagen para la breve epifanía del vivir humano; el mar es el único que durará en su «extensión colmada». Como dice en el poema 15 (p. 63), el tiempo es una mano cóncava que ya antes fue el esplendor del espacio vacuo (ver p. 27). Las geometrías que el hablante va desvelando en el paisaje se revelan vacías. La figurilla con que juega en su mano - «En tu mano girabas / la figurilla simple de un rostro que se ofrece / a la luz». (p. 63) - es trasunto del ser humano, débil muñeco en las manos del tiempo.

El dibujo en la página 58 es simplemente una cruz, que, como ya queda dicho, podría tratarse también de la inicial del apellido del pintor o de una $\mathrm{X}$, con todas sus implicaciones de tachadura, multiplicación y potencial dinámico. Ocupa un puesto más central que otros trazos ya vistos; hay una huella dactilar que se ha corrido hacia el lado izquierdo y un par de respingos, como si se tratara de marcar el territorio con lo más básico, la huella del dedo humano. La cruz en el medio es una forma de hacer hincapié en la situación de encrucijada que se viene presentando en los poemas.

En los poemas 13 y 14 se observa el mismo proceso de disolución pues la piedra permanece mientras que las inscripciones sobre las tumbas del cementerio (p. 57) se han borrado por efecto del sol, del aire y del tiempo, convirtiéndose de memento mori a ser monumentos a la desaparición de lo humano. La misma resistencia de la piedra se da en el poema 13 con los dos roques sirviendo de puntales de la luz y midiendo la extensión de la sal y del tiempo. Esos roques son, además, testigos y testimonios de la fragilidad temporal del ser humano.

El poema 16 (p. 65), se abre con la cita de Hölderlin escrita a la entrada del Museo Arqueológico de Firá en Santorini perteneciente al poema titulado «El archipiélago»: «todas viven aún, las madres de los héroes, las islas». Como el poeta alemán, Sánchez Robayna realza la permanencia de estas islas como epifanía de la duración de la belleza frente al ataque de la temporalidad. El «todas» se refiere obviamente a las islas, madres de los héroes, y enlaza con la referencia a dichas islas al final del poema anterior, reiterando el enhebrarse de estos poemas como duplicación de las islas del archipiélago. La «dispersa teoría de las islas», como escribió al comienzo, es aquí algo que se «lee», articulado a través del lenguaje mediante signos que ahora revelan, como en una epifanía, la presencia pura. El 
contrapunto es que al final es esa misma presencia la que destruye. El sol y la noche en su constante suceder son el paso temporal donde todo se diluye ${ }^{32}$.

A medida que la luz solar se intensifica con el verano, sus efectos producen «encarnaciones». Si el Verbo se hizo carne, en el poema 17 (p. 67) la luz produce sobre la piedra blanca un contrapunto entre la contención en las formas de cálices y el vuelo en las formas de palomas: «Cálices y palomas / de piedra. Blanca / piedra breve, remota». Como la piedra, el hablante quisiera transustanciarse en la luz. Un fenómeno semejante ocurre en los dibujos de Tàpies donde el pintor, al responder a las sugerencias que le hace la materia, crea la realidad en el acto de pintar.

El dibujo en la página 66, el último en esta sección, destaca por ser mucho más elaborado que los anteriores: la cruz es grande de trazos gruesos y ocupa la parte inferior; hay como un cuadrado o tipo caja que ocupa el centro, y el trazo que parece el cierre de un paréntesis o una llave se encuentra en el lado izquierdo. Los trazos son gruesos y enérgicos y no hay huellas dactilares. De la cruz parecen emanar exhalaciones, como si estuviera soportando el peso del cubo, o sugiriendo el vuelo de ese contenedor, como en las imágenes de cálices y palomas en el poema. Hay un trazo que parece un zapato, posible sugerencia de la presencia del pie humano en todo este recorrido. ¿Podría ser este dibujo la sugerencia de un mapa de las islas griegas indicando el recorrido que se ha seguido? ¿O se trata de una forma geométrica cuyo misterio queda aún por dilucidar? La curva/ paréntesis/corchete se ha reducida ante la incógnita de una forma geométrica que permanece impenetrable.

Los poemas 18 y 19 se enfocan en un pulpo y en el canto de las cigarras, formas que como la piedra, en el poema anterior, están traspasadas por la luz solar bajo "los hornos del verano»" El canto estridente de las cigarras (p. 71) acaba por fundirse con la luz llegando al punto más álgido de compenetración; el pulpo, por su parte, está fuera del mar, secándose en el vano de la puerta, fundiendo su carne con el sol. Estas criaturas logran la transustanciación deseada por el poeta.

El poema final (p. 73) comienza con la expresión de un deseo, de una plegaria pidiendo serenidad bajo el aire hirviente del verano. La voz del mar llega como en círculos, transmitiendo la confidencia de que entre sus aguas arden todos los mares del hablante: los del presente, los del pasado y los del futuro. La gran epifanía de la luz, que el hablante ha visto encarnada en el canto de las cigarras,

32. Si bien el poema se abre con una cita de Hölderlin, los versos que siguen evocan los de «La primera elegía» de Duino de Rilke:

¿Quién, si yo gritara, me escucharía entre las órdenes

angélicas? Y aun si de repente algún ángel

me apretara contra su corazón, me suprimiría

su existencia más fuerte. Pues la belleza no es nada

sino el principio de lo terrible, lo que somos apenas capaces

de soportar, lo que sólo admiramos porque serenamente

desdeńa destrozarnos.

33. Rodríguez -Refojo explica que el pulpo «es una de las figuras más frecuentes de la cerámica minoica» (Tàpies / Sánchez Robayna, p. 14). 
en el pulpo embriagado de sol, en las piedras, contiene en sí la consumación: epifanía y elegía se dan la mano.

Como ya se vio en los ejemplos analizados, el foco en poemas y dibujos es un objeto o trazo que se presenta como revelación epifánica pero ya relativizada al estar en relación con otros objetos en el contexto. Lo fragmentario y transitorio caracteriza estas obras; en Sánchez Robayna se relaciona con la experiencia del tiempo que para el poeta constituye el verdadero núcleo del poema («Dos prefacios», p. 24), y en Tàpies el fragmento se relaciona con su rechazo de la pintura académica y tiene que ver con el hecho de dejar las cosas insinuadas, inacabadas... Es una visión del mundo cercana a la cosmología china y a las ideas heraclitianas, donde la esencia del ser es el devenir, y donde las cosas se integran en un fluir continuo, y por tanto no son completas por sí mismas [...]. (cit. Triadó Tur, p. 78) ${ }^{34}$.

Las consideraciones espaciales y temporales determinan el conjunto de modo que al final no hay conclusión sino apertura y movilidad del sentido.

Contrapunto es el término del que partí para referirme a la postura vital y artística tanto en Sánchez Robayna como en Tàpies. El contrapunto en música supone un alejamiento de la monofonía para explorar distintas melodías que juegan entre sí, escuchándose simultáneamente y resultando en una armonía animada por la tensión dinámica de opuestos (Arnheim, pp. 9, 12). Aunque polifonía y contrapunto se relacionen, no son sinónimos pues el contrapunto es la base técnica en que se sustenta la polifonía. Lo polifónico se aplica bien a la poesía de Sánchez Robayna por la importancia que tienen los aspectos «carnales» del lenguaje, es decir, los valores fónicos y sensoriales, como ya noté en su primer poema; pero aún más por la filosofía o perspectiva ante la vida de este poeta. Según Sánchez Robayna, el verdadero núcleo del poema es la experiencia del tiempo («Epílogo», p. 446), de ahí que la música sea una de las artes con que más se identifica, además de la pintura. Citando al escritor y traductor italiano Claudio Magris, Sánchez Robayna cree que la poesía es la única forma de representar contradicciones sin resolverlas conceptualmente sino «componiendo una unidad superior, elusiva y musical» («Dos prefacios», p. 24). La perspectiva horizontal que ofrece en sus poemas, entre almendro y muro en el primero, por ejemplo, no otorga a ningún elemento una jerarquía superior. Se corresponde con la horizontalidad del contrapunto musical frente a la verticalidad que

34. Sánchez Robayna encuentra en el poema «Osario» de su libro Clima (1978) el inicio de la "condición general de la fragmentación de la escritura», y de Haroldo de Campos toma la expresión "poética del fragmento» y de Ungaretti su definición del fragmento como «ese trozo del discurso que, por ser en sus efectos poesía consumada, empieza desde una interrupción y termina por interrupción» («Poesía y poética», pp. 36-37). Para Laura López Fernández, Sánchez Robayna no canta el ser de las cosas sino el llegar a ser: «la representación es presentación, intuición y revelación de un mundo inconcluso» (pp. 185, 188). Se canta el ser en proceso de transmutarse, manifestándose en el mismo gesto de dejar de ser (p. 179). Por eso no se llega a ninguna conclusión definitiva, más allá de dejar testimonio de una búsqueda en la que se ha respetado la materia por lo que es, no por lo que representa. No es tanto el poeta quien formula y articula una poética, sino la realidad que le lleva a hacerlo (Palenzuela). 
caracteriza la melodía, al centrarse principalmente en las relaciones entre las notas musicales y no en desarrollar distintas melodías simultáneamente. Sin embargo, como los elementos en los poemas de Sánchez Robayna, contrapunto y armonía son funcionalmente inseparables ya que ambos, por ser elementos de un mismo sistema musical, se complementan mutuamente.

En lo que respecta a los dibujos de Tàpies, el contrapunto visual, como el musical, se basa, según Arnheim (p. 20), en dos condiciones: el contraste entre opuestos que se complementan entre sí (espacio vacío/trazo; imagen/fondo) y la semejanza o paralelismo que le hace al espectador conectar estos opuestos y, de esa manera, descubrir el antagonismo dentro de la unidad de la composición. Si en el arte convencional se prefería la jerarquía, favoreciendo la composición en la que un modelo general mantuvo la totalidad de las formas y controlaba las relaciones espaciales hasta en sus más pequeños detalles (Arnheim, p. 15), en los dibujos de Tàpies se da preferencia a unidades organizadas al azar y controladas solamente por un balance visual. En el primer dibujo analizado, se trata del contraste entre presencia y ausencia o inscripción y su huella (Arnheim, p. 13). En estos dibujos se crean, además, una serie de relaciones horizontales entre elementos tradicionalmente separados: entre pintura y escritura, entre el artista y su obra (presencia/ausencia), y entre el artista y el espectador ${ }^{35}$. La ubicuidad de la T o X o la cruz señala la insistencia de la encrucijada entre identidad e ignorancia, tachado y multiplicación, desconocimiento y potencial.

Es en esa encrucijada donde se encuentra el límite hacia otro modo de conocimiento (La práctica, p. 44). De ahí el compartido interés en ambos artistas por filosofías alternativas a las del Occidente, como el budismo y el Zen, pero también por los experimentos de dadaístas y surrealistas con su reto a la razón y la lógica y su aspiración a ver más allá de lo habitual ${ }^{36}$. En La práctica del arte Tàpies nos insta constantemente a que aprendamos a contemplar, a concentrarnos, a tener tiempo para meditar (p. 185). Y no sólo se trata de una observación intensa, labor que el pintor compara con la del científico en su laboratorio (pp. 46-47), sino de una comunión mística con lo observado, experimentando el cambio, o el «sufrir», como Tàpies dice, de una materia en proceso de cambio, el mismo «sufrir» que Sánchez Robayna confesó sentir ante los signos del paisaje de las islas (Sobre una confidencia, p. 35).

35. Raventós-Pons analiza en Tàpies la «indeterminación espacial [...] la bidimensionalidad del plano pictórico» y, mediante el uso de materias en sus cuadros, la creación de un «espacio agrietado, erosionado y triturado que acaba por espacializar el cuadro». Según la crítico, «espacio, materia y textura $[\ldots]$ se interrelacionan para engendrar una serie de oposiciones que provocan un espacio ambiguo, heterogéneo, múltiple y sensorial y que convierten la imagen en un proceso abierto» (p. 323).

36. Después de su visita a París, Tàpies empezó a usar materiales distintos del óleo y a presentar el espacio como un continuo sin ningún sistema convencional de perspectiva. Buscaba un espacio no "compuesto" sino logrado mediante la intuición. Su nueva visión del mundo podría ser compartida por un micro físico, por un lado, y un budista Zen, por otro, un mundo en el que unidades infinitésimas de materia coagulan para formar un todo físico, espiritual y humano (Ashton, pp. 31, 32). 
En ese «sufrir» en y con la materia se sitúa la horizontalidad que caracteriza la visión de estos artistas pues, como observadores, no están fuera de la escena de su observación sino inmersos en ella. Según Fernando Castro, lo que se da en la poesía de Sánchez Robayna es un "materialismo atomista», «un panteísmo sin Dios», una erradicación de lo humano por lo cual el poeta puede ofrecer «una visión fisicalista del mundo» donde el hombre ya deja de ser el punto de preferencia (p. 96) ${ }^{37}$. En esta situación, la percepción es relativa e incierta. Para J. Rodríguez Padrón, Robayna ofrece «una visión metamórfica de la realidadpaisaje, transformación que se resuelve en la incertidumbre de la visión». Y el mismo poeta admite seguir «el hechizo de la fisicalidad del mundo» («Epílogo», p. 430). Estos comentarios se aplican igualmente a la obra de Tàpies. Lo que el pintor denominó sus "pinturas de materia" responden a su visión de la pintura (hacia 1955) como "a cosmic accumulation of millions of elements» entre los que se incluyen: arena, mármol, polvo, pelo, latex, óleo, junto con sus símbolos más propios: cruces, equises, escritura tipo graffiti ilegible, números (La práctica, p. 7). Ambos artistas se fijan en objetos y cosas aparentemente insignificantes y desprovistos de interés con el fin de recordarnos que todos estamos hechos de la misma materia.

En su entrevista con Nilo Palenzuela, Sánchez Robayna se adscribe a la idea de «modernidad inconclusa» formulada por Habermas, entendiéndola como un planteamiento crítico y de rigor sobre la cuestión estética. El poeta se une así a la tradición socrática defendida también por Jürgen Habermas de asociar la autoreflexión con el diálogo, en este caso con la materia (Bernstein, p. 12). Es así que hay que entender en Sánchez Robayna lo que en Habermas se llama la «acción comunicativa», es decir, un proceso de razonamiento y entendimiento dirigido a la comunicación y el acuerdo. Al dar preeminencia a la materia, Sánchez Robayna, al igual que Tàpies, se distancia del centralismo del sujeto (Bernstein, p. 18). De igual modo, al enfocarse en eventos de la más apremiante actualidad (las víctimas del nazismo, el ataque en Atocha etc...), Sánchez Robayna sigue la pauta habermasiana de establecer un diálogo para esclarecer, mediante la obra de arte, hechos de la realidad. Lo mismo se aplica al enfoque dado por parte de ambos artistas a aspectos aparentemente insignificantes y familiares con el fin de revelar y desvelar lo que hay de nuevo en lo habitual (Habermas, p. 203). El foco en el archipiélago griego en los poemas de Sánchez Robayna indica el apoyo al legado de la tradición occidental, con la diferencia de que no se trata aquí de apoyar una razón en su aspecto pragmático y teleológico sino como capacidad para la comunicación. Sánchez Robayna concuerda con Habermas en que hay un proceso de conocimiento asociado con la obra de arte, de que podemos aprender de la experiencia artística (Bernstein, pp. 26, 28-31). El sujeto deja de ocupar el centralismo que le ha sido propio en la tradición occidental y en la filosofía de

37. Rafael Fernández Hernández señala como característico del lenguaje de Sánchez Robayna «la elisión de la presencia emocional del yo y la intensificación del poema como percepción» (p. 104). Siguiendo a Mallarmé y a Guillén, Sánchez Robayna se desprende de la anécdota y acentúa la abstracción con el consiguiente difuminar del referente poético (p. 105). 
la conciencia y del sujeto para enfocarse en la situación contextual en donde se constituye la racionalidad humana (Guiddens, p. 105). La obra de arte emerge como un modelo de reconciliación con el todo (Jay, p. 125).

Sánchez Robayna dice que "poetizar es arriesgar» y que la poesía es una «aventura del conocimiento» que funciona a modo de imán que atrae a otras artes, como la música, la pintura, pues se trata de dar forma a una conciencia, no sólo la del hablante, sino la del Occidente («Dos prefacios», pp. 24-25). En este sentido, poeta y pintor hacen eco de la interdisciplinaridad que caracterizó el Modernismo de comienzos del XX donde los artistas cultivaban distintos modos de expresión, además de mantener estrechas relaciones entre las artes. Para Sánchez Robayna, escribir es un avanzar sin saber claramente a dónde se va: «Sólo el riesgo asumido permite descubrir nuevos territorios, nuevos estados de la palabra y del espíritu» ("Dos prefacios», p. 25). Y como Sánchez Robayna, Tàpies no puede "concebir al artista si no es en plena aventura, en pleno tránsito, en pleno salto en el vacío» (p. 28). Por eso es sumamente significativo que el pintor cite a Rimbaud: «Le poète se fait voyant par un long, immense et raisonné dérèglement de tous les sens» (p. 51). Tàpies, como Sánchez Robayna, se arriesgan a explorar límites hacia un conocimiento distinto pero ateniéndose a un raciocinio particular, a un «raisonné dérèglement».

Como los títulos del libro señalan, ambos artistas buscan las correspondencias entre las cosas y escuchan las confidencias que vienen del entorno. La horizontalidad en sus visiones se desprende de su actitud ante la realidad en la que reconocen su identidad más esencial. Articulan tanto las epifanías de revelación que descubren en la materia como las elegías de su disolución. Sus obras dan forma al dinamismo en el espacio «entre», intermedio entre ambos polos del contrapunto que es la realidad. Las perspectivas que emergen de esta meditación son imprevisibles por cambiantes, lo cual supone un conocimiento distinto pues implica a lectores/espectadores, invitando a retroceder a la casa original, la materia a la que una larga tradición de enfoque en lo racional pragmático ha relegado al olvido.

Las cosas son manifestación de lo que se difumina, o el difuminar de lo presente, epifanías de la temporalidad y de las limitaciones que impone en la capacidad de conocer la realidad. Estos artistas enfocan su atención en un espacio entremedio entre presencia y ausencia, epifanía y elegía, descubriendo un contrapunto que determina el núcleo de la realidad y su naturaleza evanescente ${ }^{38}$.

38. Ultimando yo la escritura de este ensayo, Andrés Sánchez Robayna me informa por correo electrónico de la muerte de Antoni Tàpies el 6 de febrero, 2012, a los 88 años. Que este trabajo sirva de modesto homenaje a su vida y obra. 


\section{Obras citadas}

Aldrich Virgil C., "Visual Metaphor», The Journal of Aesthetic Education, 1968, 2, 1, 73-86.

Arnheim Rudolph, «A Study of Spatial Counterpoint», en Poetics of Space. A Critical Photographic Anthology, 1995, 7-22.

Ashton Dore, «Matter and Spirit: The Art of Antoni Tàpies», en Jiménez Carmen (bajo la dir. de), Tàpies, New York, Guggenheim Museum, 1995, 23-42.

Baudelaire Charles, "Correspondances», Les fleurs du mal, Paris, François Bibal, 1987.

Bernstein Richard J., «Introduction», en Bernstein Richard J. (bajo la dir. de), Habermas and Modernity, Cambridge, Massachusetts, The MIT Press, 1985, 1-32.

Borja-Villel J., «Antoni Tàpies. En perspectiva», Tàpies, Barcelona, Ministerio de Asuntos Exteriores y de Cooperación, Dirección General de Relaciones Culturales y Científicas, 2004.

Castro Fernando, "La luz que nombra», Revista de Filología de la Universidad de La Laguna, 1989, 8-9, 89-99.

Círculos de luz y otras señales del momento. Sitio de la Revista: SHARE INTERNACIONAL, [En la Red], ejemplar de Septiembre 2000, [página consultada el 2 de febrero, 2012]. Disponibilidad y acceso http://www.share-es.org/2000/sign0900.htm

Cirlot Juan-Eduardo, Significación de la pintura de Tàpies, Barcelona, Seix y Barral, 1962.

Cirlot Lourdes (bajo la dir. de), Tàpies, Barcelona, Omega, 2000.

Doce Jordi, «Camino de la inminencia», Cuadernos Hispanoamericanos, 1998, 581, 115119.

Domínguez Rey Antonio, "Luz y mirada en la poesía de Andrés Sánchez Robayna», Insula, 1985, 40, 462, 5-6.

Fernández Hernández Rafael, «En busca del cuerpo de la luz. Ante la poesía de Andrés Sánchez Robayna», Zurgai, June, 1992, 104-108.

Galván Fernando y Manuel Brito, «On the Contemporary Spanish Poetry: The Case of Andrés Sánchez Robayna», Talismán, 1991, 6, 65-71.

Gilman Ernest B., «Interart Studies and the 'Imperialism' of Language», Poetics Today, 1989, 10, 1, 5-30.

Greimas Algirdas Julien, "Figurative Semiotics and the Semiotics of the Plastic Arts, Preface to a Postface», New Literary History, 1989, 20, spring, 627-649.

Guiddens Anthony, «Reason without Revolution? Habermas's Theorie des kommunikativen Handelns", en Bernstein Richard J. (bajo la dir. de), Habermas and Modernity, Cambridge, Massachusetts, The MIT Press, 1985, 95-121.

Habermas Jürgen, «Questions and Counterquestions», en Bernstein Richard J. (bajo la dir. de), Habermas and Modernity, Cambridge, Massachusetts, The MIT Press, 1985, 192-216.

Hölderlin Friedrich. [En la Red]. [Página consultada el 9 de febrero, 2014]. Disponibilidad y acceso http://www.ophelia.4t.com/archipielago.html

Jay Martin, «Habermas and Modernism», en Bernstein Richard J. (bajo la dir. de), Habermas and Modernity, Cambridge, Massachusetts, The MIT Press, 1985, 125-139.

Johns Bethany, «Visual Metaphor: Lost and Found», Semiótica, 1984, 52, 291-333.

Jongh Elena de, Florilegium. Poesía última española, Madrid, Espasa-Calpe, 1982.

Kibédi Varga A., «Criteria for Describing Word-and-Image Relations», Poetics Today, $1989,10,1,31-53$. 
López Fernández Laura, «El esencialismo en la poesía de Andrés Sánchez Robayna», Anales de la literatura española contemporánea, 2000, 25, 1, 171-191.

Malpartida Juan, "Cuerpo sumergido (Sobre Andrés Sánchez Robayna)», Cuadernos Hispanoamericanos, 1991, 498, December, 41-47.

Mayhew Jonathan, "Valente / Tàpies: the Poetics of Materiality», Anales de la literatura española contemporánea, 1997, 22, 1-2, 91-102.

Miranda Cirlot Sandra, Tàpies, Barcelona, Fundació Antoni Tàpies, Vegap, 2001.

Monegal Antonio, «Más allá de la comparación: fusión y confusión entre las artes», Revista Canadiense de Estudios Hispánicos, Reproducciones y Representaciones, Diálogos entre la imagen y la palabra, 2003, otoño, 28, 1, 27-44.

Palenzuela Nilo, «Conversación con Andrés Sánchez Robayna», Ínsula, 1985, 40, 462.

Raventós-Pons Esther, «Espacio, materia y textura en las pinturas de Antoni Tàpies», Revista Canadiense de Estudios Hispánicos. Estudios en honor a Mario J. Valdés, Otoño 2001/Invierno 2002, 26, 1-2, 323-336.

Rilke, Rainer Maria. [En la Red]. [Página consultada el 8 de febrero, 2014]. Disponibilidad y acceso: http://www.epdlp.com/texto.php?id2=1216

Rodríguez Padrón Jorge, "Andrés Sánchez Robayna: La palabra insular», Insula, julioagosto 1979, 392-393, 1, 24.

Rodríguez-Refojo Alejandro, "De la poesía a la pintura: "Sobre una confidencia del mar Griego”. Entrevista a Andrés Sánchez Robayna», Tàpies / Sánchez Robayna, Las Palmas de Gran Canaria, Fundación Mapfre Guanarteme, 2006, 39-46.

Sánchez Robayna Andrés, Correo electrónico, 18 de Enero, 2012.

— «Dos prefacios», Cuadernos Hispanoamericanos, 2010, 723, 23-27.

— «En la práctica del "diario”", Cuadernos hispanoamericanos, 1997, 560, 39-42.

— «Epílogo del autor», En el cuerpo del mundo. Obra poética (1970-2002), Barcelona, Nueva Galaxia Gutenberg, 2004, 425-446.

— «Poesía y poética», Syntaxis, 1985, 7, 27-42.

— «Sobre Tàpies», Tàpies / Sánchez Robayna, Las Palmas de Gran Canaria, Fundación Mapfre Guanarteme, 2006, 47-67.

- Tàpies / Sánchez Robayna, Las Palmas de Gran Canaria, Fundación Mapfre Guanarteme, 2006.

Sánchez Robayna Andrés y Antoni Tàpies, Sobre una confidencia del mar griego. Precedido de Correspondencias, Madrid, Huerga y Fierro, 2005.

Scott Clive, «Symbolism, Decadence and Impressionism», Modernism. A Guide to European Literature 1890-1930, en Bradbury Malcom y McFarlane James (bajo la dir. de), London, Penguin Books, 1991, 206-227.

Tàpies Antoni, La práctica del arte, tr. Joaquin Sampere, Barcelona, Ariel, 1971.

- Tàpies / Sánchez Robayna, Las Palmas de Gran Canaria, Fundación Mapfre Guanarteme, 2006.

Triadó Tur, Miranda Cirlot Juan-Ramón y Sandra, Tàpies. Barcelona, Fundació Antoni Tàpies, Vegap, 2001.

Valente José Ángel, Material memoria: trece años de poesía 1979-1992, Madrid, Alianza, 1995. 